\title{
From international to global understanding: toward a century of international geography education
}

\section{Rafael De Miguel González}

To cite this article: Rafael De Miguel González (2020): From international to global understanding: toward a century of international geography education, International Research in Geographical and Environmental Education, DOI: 10.1080/10382046.2020.1809792

To link to this article: https://doi.org/10.1080/10382046.2020.1809792

曲 Published online: 25 Aug 2020.

Submit your article to this journal $\widetilde{ }$

Џ Article views: 126

Q View related articles ¿

View Crossmark data ¿ 


\title{
From international to global understanding: toward a century of international geography education
}

\author{
Rafael De Miguel González \\ Faculty of Education, University of Zaragoza, Zaragoza, Spain
}

\begin{abstract}
The Commission on Geographical Education of the International Geographical Union has stated along their history different documents that serve as a reference on how to carry out the teaching and learning of geography at schools, called the International Charters on Geographical Education. The preliminary documents to the first Charter were founded on the concept of international understanding to promote international collaboration on geography education. The latest Charter has been approved in 2016, which was proclaimed as the International Year of Global Understanding, in the $33^{\text {rd }}$ International Geographical Union Congress. In each of these documents, a main subject is underlined that places special emphasis on teaching and learning geography as a school discipline, reflecting not only the evolution of educational thought but also the social and political contexts in which it falls. Besides, each Charter underlies a manifestation, more or less implicitly, of international educational aims due to the significance of geography and its values in understanding and acting in the world from a social and spatial perspective.
\end{abstract}

\section{KEYWORDS}

International understanding; global understanding; international charter; Commission on Geographical Education

\section{Introduction}

From 1919, just at the end of World War I until the mid-twenties of the past century, that is around one hundred years ago, geographers' community defined the concept of international understanding as a basis for international cooperation on geography education worldwide and promotion of geography education in developing countries. The formal establishment of the International Geographical Union (IGU) in Brussels in 1922 contributed to the dissemination of this concept. The centennial IGU Conference to commemorate its foundation, which is to be held in Paris in 2022, will also be a special moment to assess the recent history of geography education directly related to the "centennial +3 " concept of international understanding. About one century after IGU's foundation, a new concept has been defined to guide geography as a scientific discipline and serve as a guiding light to the IGU Commission on Geographical Education (CGE): global understanding. In 2015, the three international 
science councils (International Council for Science, International Social Science Council, and International Council for Philosophy and Human Sciences) together proclaimed 2016 as the International Year of Global Understanding. In 2016, the $33^{\text {rd }}$ IGU Conference held in Beijing included global understanding as a key topic. 2016 marked the first of the fifteen years for the implementation of the Sustainable Development Goals (2015-2030) based on the global challenges faced by the humankind.

One century later than 1919, today we live and teach geography in different political, economic, and social contexts than the post-World War I era. During this long period, IGU has approved several charters and declarations to promote international guidelines for geography education, with references to both international understanding and global understanding. Despite the existence of UNESCO's previous texts on geographic education - particularly those from 1949, 1951, 1965, and 1982 - the first International Charter on Geographical Education dates back to 1992. It was based on raising awareness among the new generations about the challenges faced by planet Earth as indicated by the Universal Declaration of Human Rights (1948), United Nations (UN), and United Nations Educational, Scientific, and Cultural Organization (UNESCO) that include hunger, poverty, illiteracy, violation of human rights, lack of peace, and justice, along with those challenges with a geographical dimension such as migration, climate change, deforestation, and globalization. The Charter was mainly based on the UNESCO Recommendation on Education for International Understanding, Cooperation and Peace (1974), an international reference that considered the right to education as a way to promote understanding, tolerance, and friendship among the nations of the planet; and to face the aforementioned challenges of humanity.

The three subsequent declarations thematically supplemented the initial one. The International Declaration on Geographical Education for Cultural Diversity (2000) expanded the vision of geography education: improving the capacity of all citizens to contribute to creating a just, sustainable, and pleasant world, but bearing in mind the respect for cultural diversity, lifestyles, and social contexts of different people on planet Earth. The International Declaration on Geographical Education for Sustainable Development (2007) has been inscribed in the principles of the United Nations Decade of Education for Sustainable Development (2005-2014), transferring the paradigm of sustainability to all areas of education in order to seek a positive transformation of society. International Declaration on Research in Geography Education (2015) strongly commended the value of research in geography education to inform, to underpin and to evaluate progress in geography education.

After these two additions to the original Charter of 1992, IGU has approved a new International Charter on Geographical Education in 2016 because IGU felt the previous one was out of date in a new context: the development of geography as a science, the evolution of geographical education, and the spatial challenges facing humanity (as recently expressed in the Sustainable Development Goals or Paris Agreement on climate change). The new Charter maintains most of the previous principles, and adds some others, such as global understanding, active citizenship in a global world, and acquisition of spatial skills for the use of digital cartographic tools, among others. 
In other words, pragmatism is agreed in this new Charter that it is articulated around an International Action Plan on geography education addressed to the educational policy-makers, curriculum developers, geography educators, and geography teachers, from elementary to higher education levels.

During the elaboration and dissemination phases, the different charters and declarations served as forums for reflection and debate on discourses not only between the different members of the IGU-CGE (Bourke \& Lane, 2018), but also within other important associations dealing with geography education such as the National Council for Geographic Education (NCGE), the European Association of Geographers (EUROGEO), the Geographical Association (GA), and the American Association of Geographers (AAG). Moreover, these documents have contributed toward raising awareness about the importance of international collaboration in geography education among the aforementioned organizations and other geographers (Bednarz, Burkill, Lidstone, \& Rawling, 2000; Donert, Hay, Theobald, Valiunaite, \& Wakefield, 2011; Higgitt et al., 2008; Klein \& Solem, 2008). This study examines, using a critical historiographical methodology, the pendulum swing between the concepts of international and global understanding along the last century as an important epistemological approach to geography education.

\section{International understanding through the teaching of geography: Historical background}

\section{9-1939}

The academic references on geography education and international understanding and consequently the importance of teaching geography as a factor in the construction of peace between nations - go back more than three decades before the creation of the IGU Commission addressing "Geography in Schools" in 1952 at the seventeenth IGU Congress in Washington DC. On June 18, 1919 the Treaty of Versailles was signed, which includes repeated references to cooperation between nations to guarantee peace and international security after the war. The first part of the Treaty (Articles 1 to 26) included the Covenant of the League of Nations. This institution promoted the concept of international understanding, which had a special echo in the World Federation of Education Associations (WFEA), created in 1923 in San Francisco but legally established in 1925 at its first World Conference in Edinburgh (Smith, 1944).

Geographical Association's first journal (appeared in 1901), The Geographical Teacher, included two preliminary references to international understanding. In 1920, this association was opened to geographers outside the United Kingdom and started allowing membership from all continents in the world. One objective of this was the internationalization of the Association, and particularly of its academic production and journal. Thus, Fleure (1919) stated at the Editorial journal that the Geographical Association was taking "efforts for international understanding" just several weeks after the Treaty of Versailles was signed. Later, the Annual Report for 1920 recognized that the growth of overseas membership was "helping education and international understanding" as "the continuous growth in importance of international 
questions makes our claim ever stronger: geographical education - school education and higher education - is one of the essentials for the development of international peace" (Fleure, 1921).

One year later, Atwood (1922) wrote another paper about the integration of geography, world relations, and international understanding. Afterward, Geography in School, one of the most influential books on geography education for decades, claimed a place for geography in the curriculum. Geography education enables to understand other people and places "to train future citizens to imagine accurately the conditions of the great world stage, and so help them to think sanely about political and social problems in the world around" (Fairgrieve, 1926).

Furthermore, WFEA's first President published a more detailed paper about international understanding through teaching of geography (Thomas, 1932). Following the studies on geography education (there are not too many) has also contributed to the reflection on international understanding (Gandy, 1963; Lidstone \& Stoltman, 2002; Ursula, 1955). Nevertheless, the most powerful contribution to the dissemination of international understanding in geography education has been made by the IGU and UNESCO partnership, as later explained.

IGU establishment as a permanent organization was an important milestone and promoted International Geographical Congresses. From the Cairo (1925), Cambridge (1928), and Paris (1931) Congresses, there is no record of a group of participants related to geography education. In the Warsaw Congress (1934), the fourth section was regarding the methods of teaching geography, and there were sixteen contributions (International Geographical Union, 1935). In the Amsterdam Congress (1938), in its sixth section (methodology and didactics) were presented two contributions directly related to the aforementioned paper written by Thomas six years before: the importance of geography in developing a good understanding between nations. Both Orford (British) and Portengen (Dutch) did one contribution each regarding geography's usefulness as a school discipline, beyond knowing the political geography and changes of the borders, in understanding the international diversity of landscapes, cultures, and means of production. The former suggested a complementary vision for international understanding by teaching "geography of human relations" based on the good understanding among the people of the planet (Orford, 1938). Unfortunately, it was written in the context of confrontations prior to World War II and the Munich Agreement (later confirmed as a total failure of the appeasement policy).

\section{9-1951}

In 1939, the International Bureau of Education (IBE, integrated into UNESCO since 1969) published a first report on "The Teaching of Geography in Secondary Schools, according to the data provided by Ministries of Education" that contributed to reinforce the international perception of geography education. The year also marked the end of the dream of international peace as World War II started. After the War, two international organizations were established, the UN and UNESCO, whose foundational charters included universal principles and international rights for the whole of humanity. The San Francisco Charter of 1945, the foundational treaty of the UN, 
wrote in its Preamble the principles of peace, justice, freedom, economic and social progress, equality, and human rights. The latter principles were published in 1948 in the Universal Declaration of Human Rights.

The second body, UNESCO, an organ of the UN, was also formed in 1945 with the aim of contributing to the achievement of peace through education and culture. The Constitution of UNESCO, reaffirming the main principles expressed in the Charter of San Francisco, established as its main purpose the promotion of mutual knowledge and understanding among nations as a means to maintain world peace and avoid a Third World War. As described by the second President of the Commission on Geographical Education (Brouillette \& Vilá Valentí, 1971), UNESCO was interested in geography, history, and social sciences as strategic disciplines for the achievement of its objectives from the very beginning. Thus, in 1949, UNESCO fostered three initiatives that are key to understand the later development of geography education worldwide:

1. The approval of Recommendation number 26, presented at the $12^{\text {th }}$ International Conference on Public Instruction and addressed to the Ministries of Education of UNESCO Member States, entitled "The Teaching of Geography and International Understanding" (UNESCO, 1949a): It was urged to abandon a geography syllabus exclusively focused on the respective country, and adopt a comparative teaching with other nations and other geographical spaces. UNESCO believed that conformation of a national identity and love for own country with understanding and respect toward the rest of the nations, all possessing equal rights, is compatible.

2. The publication of "Handbook for the improvement of textbooks and teaching materials as aids to international understanding" (UNESCO, 1949b), which was disseminated at the Montreal seminar in 1950, specific to geography: the teaching of geography as a means of developing international understanding. The first General Conference of UNESCO in 1946 had drawn attention to the ethnic and political indoctrination carried out in the German educational system of the Third Reich through textbooks. That is why UNESCO focused its action on school textbooks, especially those of geography and history (Power, 2015). This debate of textbooks brought as a consequence the creation of the Georg Eckert Institute for the International Research of Textbooks in 1951. Its initial task was the constitution of a French-German commission in that same year for the revision of the textbooks of geography and history based on the principle of reciprocal understanding. It meant the reconciliation and finalization of a rivalry manifested from the colonial era, the Franco-Prussian War, and later in both World Wars. In this sense, it is not a coincidence that the Treaty of Paris was signed and the European Coal and Steel Community (ECSC) was formed as the first step toward the European Communities (similar to today's European Union) in the same year of 1951.

3. The publication, as Volume VII of the UNESCO Series on International Understanding, of a booklet entitled "Some suggestions on the teaching of geography” (UNESCO, 1949c), edited by Robert Ficheux: It began with a reminder 
of UNESCO's mandate to "consolidate through education that foundation of peace that is based on the knowledge and mutual understanding of the peoples". Besides, the $16^{\text {th }}$ IGU Congress was held in Lisbon in 1949, the first in eleven years after the Amsterdam Congress in 1938 because of World War II. A Geography Teaching Committee, an embryo of the future Commission, chaired by Neville Scarfe was organized in this Congress. Some months later, he became the counselor of the Joint Seminar (Committee Teaching IGU-UNESCO) of Montreal in 1950, and used the aforementioned booklet as a documentation of the debates and studies. After the deliberations of the seminar, this document was reviewed by Scarfe himself and published with the new title of "Handbook of Suggestions on the Teaching of Geography: Towards world understanding" (UNESCO, 1951). It was widely disseminated by UNESCO and translated to several languages, and also was the main reference for the 1965 source book, as later described.

\section{UNESCO supporting the IGU-CGE, 1952-1982: improving geography teaching and international understanding}

The IGU Commission called "Teaching Geography in Schools" was formed in the $17^{\text {th }}$ IGU Congress held in Washington D.C. in 1952, not without difficulties (Brouillette \& ViláValentí, 1971; Lidstone \& Stoltman, 2002) despite a blurry precedent from 1904 (Schneider, 1972; Wise, 1992). The first President was Neville Scarfe who continued his leadership until the $18^{\text {th }}$ IGU Congress held in 1956 in Rio de Janeiro, when Benoit Brouillette was elected as the new President of the Commission. The IGU-CGE got its current name in the $21^{\text {st }}$ IGU Congress held in 1968 in New Delhi.

\section{UNESCO source book for geography teaching, 1965}

Brouillette reinforced the relationship between the IGU Commission and UNESCO thanks to the signatures of several research contracts since 1957. They had the following aim of preparing a work, "as a guide or of manual, for the use of the teachers, that would make them better understand Geography and incite them to inculcate it to their students according to the principles of mutual understanding among the peoples of the whole world (Brouillette \& Vilá Valentí, 1971).”

Some of the research achievements were presented at the $20^{\text {th }}$ IGU Congress held in London in 1964. However, the final outcome was the publication of the UNESCO Source Book for Geography Teaching (UNESCO, 1965), which had a great international diffusion not only for its translation to eleven languages but also for becoming the reference manual for the training of geography teachers in many countries. Two supplementary books were published later as a regional implementation of the Source Book, one for Africa (Brouillette, Graves, \& Last, 1974) and one for Latin America in Spanish (Brouillette \& Vilá Valentí, 1975).

The Source Book begins with a declaration of principles - mutual understanding among people, global literacy, and youth civic education - but also includes useful pedagogies such that the manual could be used in schools in all countries and 
contexts. Teaching geography approaches were based firstly on the local and regional spatial problems as they were more accessible to students, thus allowing later the change of scale to the national and international scales, as well as teaching international understanding and international solidarity.

\section{UNESCO recommendation, 1974}

Nevertheless, the institutional recognition of international understanding and the contribution of geography happened in 1974. During the implementation process of the Source Book, UNESCO approved the "Recommendation concerning Education for International Understanding, Cooperation and Peace, and Education related to Human Rights and Fundamental Freedoms." In other words, an international agreement confirmed the principles of the Source Book for geography teaching and also encouraged the UNESCO member states to include, within the respective guidelines of their education policy, the international dimension of the processes of training people to develop students' knowledge, capacities, and attitudes. For this, Section 45 of the Recommendation also encouraged "wider exchanges of textbooks, especially history and geography textbooks and other educational materials in order to ensure that they are accurate, balanced, up to date and unprejudiced and will enhance mutual knowledge and understanding between different peoples.”

\section{New UNESCO source book for geography teaching, 1982}

The historical context of the revision of the method was very different than two decades before. In the case of geography, international understanding was even more evident as the $23^{\text {rd }}$ IGU Congress was held in 1976 in Moscow, but political rivalries between the U.S. and USSR barely interfered in the advancement and consolidation of international collaboration in geography research. However, the UNESCO Source Book for Geography Teaching written by the Chair of IGU Commission on Geography Education between 1972 and 1980 hardly included any reference to international understanding (Graves, 1982). This new source book was essentially oriented toward the postulates of new geography and quantitative geography but also to the economic, social, ecological, and spatial values of geography as a school discipline. It also included the new pedagogical language like curriculum organization, instructional design, problem-solving, and evaluating learning outcomes. In the beginning of the eighties, it seemed that the old concept of international understanding defined at the age of big conflagrations was totally old-fashioned as the new world challenges, and, therefore, the spatial challenges, were different: escalation of the Cold War, economic crisis and oil trade, ecological problems, and the incipient technological revolution.

\section{The age of charters and declarations for international geography education: 1992-2016}

Joe Stoltman, Chair of the IGU Commission on Geography Education between 1980 and 1988 recognized the conceptual shift from international understanding to 
international education and global issues, particularly after the Global Geography Project implementation (Lidstone \& Stoltman, 2002) (Stoltman, 2006). The Chairs of the Commission between 1988 and 1996 (Haubrich, 2006), and between 1996 and 2000 (Gerber, 2003) agreed with the increasing global agenda for geography education in the last two decades of the twentieth century.

\section{International charter on geographical education, 1992}

The $27^{\text {th }}$ IGU Congress held in 1992 in Washington D.C. again proclaimed the International Charter on Geographical Education. This document was supported in the principles set out in the aforementioned UN and UNESCO Charters, Constitutions, and Declarations, and particularly the UNESCO Recommendation of 1974 concerning Education for International Understanding. However, this was the only mention to this expression in the IGU Charter. As explained in the previous paragraph, global approach was introduced in geographical education literature, and the Charter proclaimed the "right to high quality geographical education, both a balanced regional and national identity and a commitment to international and global perspectives." Thus, seventy-three years later, the foundational aim of geography education has changed from international understanding to international and global commitment. In other words, the world has changed enormously in the past decades. Geography has become much more complex as a science. Moreover, geographical education needed a further reflection to enable students to develop knowledge, understanding, skills, and values regarding the increasing society-environment relationships, spatial interconnections, environmental impacts, and scale interactions.

Based on the UNESCO Recommendation of 1974, the Charter highlighted the importance of international geography education in promoting understanding, tolerance, and friendship among all nations from an "international dimension and a global perspective." International understanding was once again replaced by awareness of global interdependence, along with international solidarity and cooperation. Thus, the Charter focused on International Cooperation to promote bilateral or multilateral exchanges for geography educators from all the countries. The consolidation of an international geography education workforce has been possible through the IGUCGE, international geography associations (in particular EUROGEO, founded in 1979, whose previous name ESCGTA was included in the Charter Appendix A), and national geography associations as active stakeholders who meet the national education policy makers to set curriculum (Stoltman, 1997).

\section{International declaration on geographical education for cultural diversity, 2000}

Nevertheless, the Chair of the Commission realized that the ideal of standardized geography education worldwide was impossible to achieve considering the diverse status of geographical education from nation to nation. Resultantly, Rod Gerber wrote a draft of an International Declaration on Geographical Education for Cultural Diversity, which was presented and approved at the general business meeting of the IGU-CGE held in 2000 in Seoul, chaired by Lea Houtsonen. The concept of 
international understanding was not included in the new document that was based on the statement, "geographical research and teaching makes a major contribution to our understanding of the cultural, social and industrial environments of the world." This statement was clearly influenced by the foundational expression as analyzed by Graves and Stoltman (2015) who thought that cultural diversity and the acceptance of diversity are components of international understanding, and not the driving idea behind it. Simultaneously, and without prejudice of the Declaration's positive contributions to the human, cultural, social, and environmental sides of geography education, the document concluded with the expression of "global geographical education," thus strengthening the global approach for the forthcoming references.

\section{Lucerne declaration on geographical education for sustainable development, 2007}

Past Chair of the IGU Commission, Hartwig Haubrich, together with Sibylle Reinfried and Yvonne Schleicher, presented a Declaration on Geographical Education for Sustainable Development in the Regional Symposium of the IGU-CGE in Lucerne in 2007. It was approved by the Commission (chaired by Lex Chalmers) as an opportunity to confirm its commitment to education for sustainable development particularly because 2005-2014 was the UN Decade of Education for Sustainable Development. Despite being considered as an extension on the International Charter de 1992, the title did not include the word international as it was focused on the concept of sustainable development, strategies for implementing sustainable development, geographical competencies and curricula for education to enhance sustainable development, and the importance of Information and Communication Technologies (ICT) in geographical education. Nevertheless, some interesting ideas can be found in the international education discourse that this study addresses. First, the Declaration had expressed that it was "unwise to seek consensus on a global curriculum". It aimed national curricula containing national and regional needs, knowledge, skills, and attitudes to face global problems and geographical phenomena that are of global dimension. The document highlights the expression global learning based on an intercultural understanding, which is possible because of the development of ICT, digital media, online collaboration, and international cooperation.

\section{Contemporary times: implementing an international action plan for global understanding}

\section{3-2016}

The two extensions of the International Charter have not been enough to update the document to accommodate the social, educational, and geographical context. The international community of geography educators must be even more actively engaged to global ethics in geography education so that a stronger global leadership in geography education is claimed if they want to influence the processes of global education and globalization (Haubrich, 2009). Consequently, three important documents have been introduced to reinforce the international collaboration in geography education 
for the global world and as preliminary works for the new and updated International Charter approved in 2016.

In 2013, a Joint Declaration on Geographical Education in Europe was signed by IGU (and CGE), EUROGEO, and EUGEO. It has been an affirmation that the teaching of geography in schools is fundamental for the future of Europe, and requested academic recognition in the official curricula with sufficient time for the teaching of geography and qualified training for geography teachers.

In 2014, one of the two co-chairs of the IGU Commission, Joop Van der Schee, presented an International Strategy for Geography Education at two events: EUROGEO Conference held in Malta and IGU Regional Conference held in Krakow, Poland. This document claimed for the need of developing an international research agenda for geography education that is supported by a strong professional network of geography educators.

International Declaration on Research in Geography Education was proclaimed at the IGU Regional Conference held in Moscow in 2015. Through this document, the IGU Commission aimed to develop an international culture in geography education in which research investigations at a variety of scales are planned and conducted by means of an international collaborative approach.

Two other important milestones of the year 2015 are the Paris Agreement within the United Nations Framework Convention on Climate Change and Sustainable Development Goals set by the United Nations General Assembly. These initiatives do not belong particularly to geographers; however, their real impact on the global agenda is so powerful that any kind of updated geography education needs to incorporate them because of their spatial dimension.

\section{International charter on geographical education, 2016}

Two co-chairs of the IGU Commission prepared the International Charter on Geographical Education, 2016: Joop van der Schee and John Lidstone. Draft versions have been discussed with representatives of EUROGEO, EUGEO, AAG, SEAGA, and others for international agreement on geography education. The new Charter has been endorsed by the $33^{\text {rd }}$ IGU Congress held in Beijing in 2016. It begins by acknowledging the preceding documents, particularly the 1992 Charter, but also the 1974 UNESCO Recommendation and Sustainable Development Goals, 2015. Thus, it combines the heritage of international understanding with the new UN global challenges and goals.

Nevertheless, a simple analysis of the document shows the difference in the use of both terms: the term global appears only six times in the new Charter, mostly to define the current world system (global scale, global perspectives, global economy, global interconnections); on the other hand, the term international is used 40 times in a 10-page document. Apart from the ones used in International Geographical Union, International Charters, and International Declarations, there are many other instances where the term is used as the new Charter proposes and advocates for International Cooperation and an International Action Plan. At the age of globalization, it is clear that the international geography education approach is even more 
needed than one century ago. In the foundational times, it was important due to the contribution of geography education to international understanding for the development of international peace. Today, the significance of international understanding lies in the contribution of geography education for understanding global challenges like sustainable development, climate change, globalization -economic, cultural and social in global due to advances in transportation and communication technologiesor progress of multilateralism and global geopolitics after the end of the Cold War.

\section{Geography education for global understanding}

Even though the new Charter does not contain the expression global understanding, the links between both are quite evident. First, 2016 was proclaimed International Year of Global Understanding, with the support of the IGU. Global Understanding was one of the five key topics for the $33^{\text {rd }}$ IGU Congress, where the new Charter was approved. Besides, one plenary session and several parallel sessions where dedicated to the theme of global understanding.

IGU has been supporting the initiative since then (its status can be checked currently on their webpage) and will continue supporting in the next future, the $34^{\text {th }}$ IGU Congress in 2020 in Istanbul (postponed to 2021) and the Centennial Conference in 2022 in Paris. The IGU-CGE has paid special attention to global understanding in two ways. Both its Symposia in 2017 (Lisbon) and 2018 (Quebec), with the new Charter implemented, included special sessions on global understanding. Secondly, one of the three books published within the flagship initiative from the IGU Commission - International Perspectives on Geographical Education Series at Springer - is titled Geography Education for Global Understanding (Demirci, De Miguel, \& Bednarz, 2018). It contains twenty-one contributions, most of them linking global understanding to the new 2016 Charter, including its incumbent co-Chair (Chew-Hung Chang), the incumbent President of EUROGEO (Rafael de Miguel), the past Chair of the Commission and co-author of the 2016 Charter (Joop van der Schee), and the past President of the AAG (Sarah Bednarz).

Finally, the principles of global understanding and the new Charter share a common approach to geography education: bottom-up processes for a quantitative and qualitative improvement of geography in education, and for better-educated citizens who contribute to a better society. Both principles underline the need for commitment from the international community of geography educators (Stoltman, Lidstone, \& Kidman, 2017) as learning geography is an educational right for every human person, and understanding sustainable development in the global context is a basic condition to protect Earth's future.

\section{Findings and conclusions in 2019}

Findings from the diachronic analysis of the international approaches from the perspective of the milestones in geography education are summarized in Table 1 to compare the conceptual evolution from international understanding to global understanding as a main trend in the centennial trajectory of internationalization of geography education. 


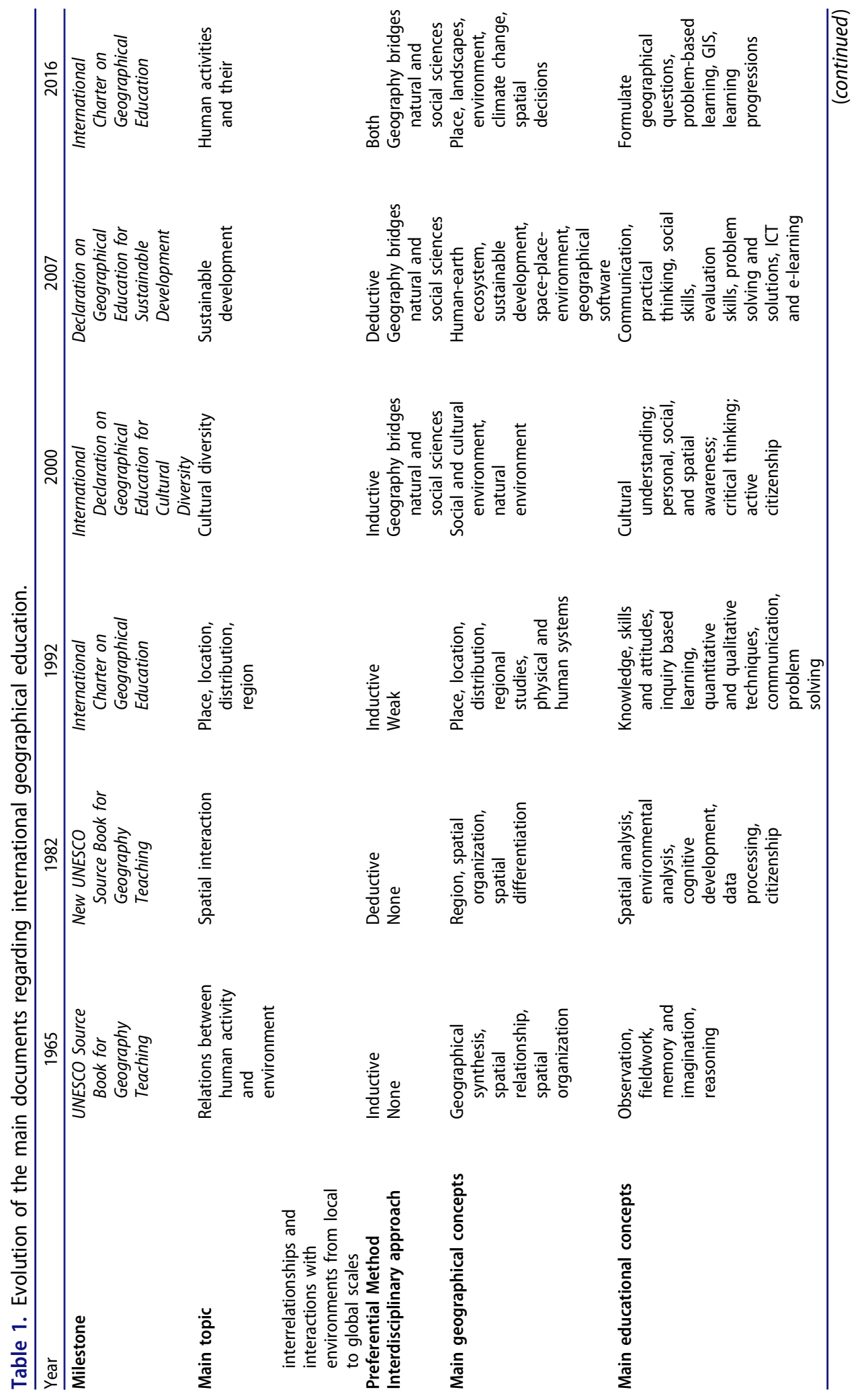




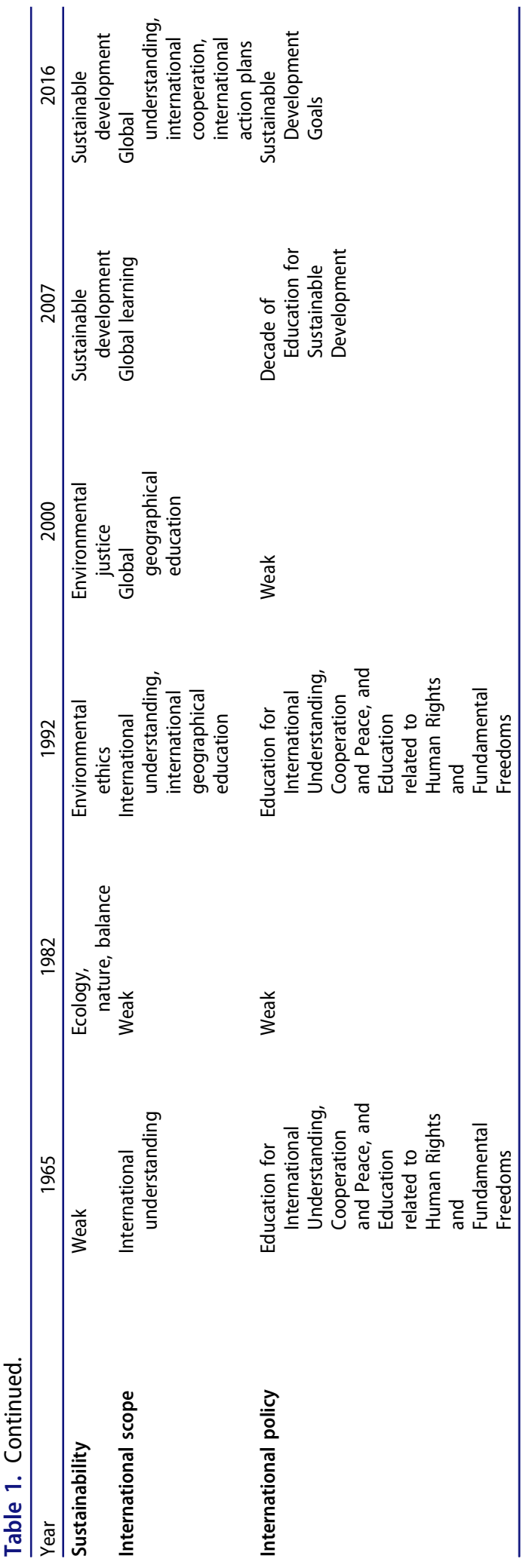


The different papers, documents, charters, and declarations made by the international community of geography educators reflect diverse approaches: world peace (1965), theoretical foundations of geography as a school discipline (1982), education for development (1992), cultural diversity (2000), sustainable development (2007), and global understanding (2016). Nevertheless, some critical conclusions can be made. First, each document is the product of their respective time, be it political, socio-economic, or cultural. Moreover, each item reflects the state of the art for the dominant epistemological approach of geography as a scientific discipline. Irrespective of the prevailing current, all contributions have pursued the same aim: achieving a better academic and scholastic status for geography in every country and school in the world, and teaching geography updated to their contemporary times.

Thus, these documents initially focus on the political side of geography - nearly related to history as a school discipline - clearly influenced by regional geography. Later, the quantitative revolution meant a paradigm shift in geography, and also in teaching geography, as it can be confirmed from the New Source Book of 1982. The crisis of logical positivism allowed the introduction of environmental and critical (cultural, postmodern, humanist, and radical) geography approaches into international geography education. Some of the ideas or goals expressed in the past are still valid, and some others are obsolete despite the general target of increasing international cooperation among the community of geography educators.

Currently, the world is more complex and more interconnected than ever to be taught from a geographical perspective. Therefore, the global understanding approach is needed to implement a holistic learning of the Earth and the society processes and phenomena at the beginning of the $21^{\text {st }}$ century. The fear of another war, a kind of obsession in the past decades, later prolonged by the Cold War and the risks of a Third "nuclear" World War, has been a constant in the political agenda and, therefore, in the educational discourses on social sciences. Today, we attend to regional conflicts or political confrontations due to religious or nationalist reaffirmations, which geography education must address. The world conflicts nowadays are virtual with a technological, environmental, or trade aspect attached more than the army one. Let us take three examples: the confrontation between China and the United States over tariffs, $5 \mathrm{G}$ networks, and the fulfillment of Paris Agreement for climate change. Any of these examples or others like natural risks and hazards, population growth, and most of the Sustainable Development Goals has an indisputable spatial and geographical approach. One of the most important lessons learnt from Covid-19 pandemic is that geographical space matters because its global way of transmission. Again, mutual suspicions between China and the United States as global superpowers (reciprocal accusations about the origin of the infection, race to get the vaccine, withdrawal of the WHO) are based on a lack of international understanding, with indisputable consequences on global geopolitics.

Therefore, a combined international and global geographical approach is more needed today than ever before in a more complex framework of geography as a reference (both as a disciplinary science and a higher education field) for geography as a school subject. In the times of neo-geography and cyber-geography, the borders of the geographical knowledge are becoming more and more blurry. Thus, international 
geography education -one century after 1919- is vital for the contribution to a more ethic and creative citizenship; and also, for the global understanding among the people of the world.

\section{Disclosure statement}

No potential conflict of interest was reported by the author.

\section{References}

Atwood, W. (1922). Geography and world relations. Journal of Geography, 21(3), 81-89.

Bednarz, S., Burkill, S., Lidstone, J., \& Rawling, E. (2000). The international network for learning and teaching geography: Developing links with school education. Journal of Geography in Higher Education, 24(2), 277-284.

Bourke, T., \& Lane, R. (2018). A comparison of the international charters on geographical education. Journal of Geography, 117(4), 174-180.

Brouillette, B., Graves, N., \& Last, G. (1974). African geography for schools: A handbook for teachers. London: Longman.

Brouillette, B., \& ViláValentí, J. (1971). Las comisiones La Enseñanza de la Geografía y La Geografía en la educación de la Unión Geográfica Internacional. Revista de Geografía, 5, 85-107.

Brouillette, B., \& ViláValentí, J. (Eds.). (1975). Geografía de América Latina: Métodos y temas monográficos. Barcelona: Teide.

Demirci, A., De Miguel, R., \& Bednarz, S. (Eds.). (2018). Geography education for global understanding. Dordrecht: Springer.

Donert, K., Hay, I., Theobald, R., Valiunaite, V., \& Wakefield, K. (2011). International collaboration in organizations promoting geography education: Exploring success and acknowledging limitations. Journal of Geography in Higher Education, 35(3), 445-455.

Fairgrieve, J. (1926). Geography in school. London: University of London Press.

Fleure, H. (1919). Editorial. The Geographical Teacher, 10(3), 77-79.

Fleure, H. (1921). Annual report, 1920. The Geographical Teacher, 11(1), 1-2.

Gandy, W. (1963). Geography and international understanding. Journal of Geography, 62(5), 193-197.

Gerber, R. (2003). Globalization and geographical education. In R. Gerber (Ed.), International handbook on geographical education (pp. 21-33).Dordrecht: Springer.

Graves, N. (1982). New UNESCO source book for geography teaching. London: Longman.

Graves, N., \& Stoltman, J. (2015). The Commission on Geographical Education of the International Geographical Union 1952-2012. Manuscript review paper. Retrieved from http://www.igu-cge.org/wp-content/uploads/2018/02/The-IGU-Commission-on-GeogEducation-modified-0915.pdf.

Haubrich, H. (2006). Changing philosophies in geographical education from the 1970s to 2005: An international perspective. In J. Lidstone \& M. Williams (Eds.), Geographical education in a changing world: Past experience, current trends and future challenges (pp. 39-53).Dordrecht: Springer.

Haubrich, H. (2009). Global leadership and global responsibility for geographical education. International Research in Geographical and Environmental Education, 18(2), 79-81.

Higgitt, D., Donert, K., Healey, M., Klein, P., Solem, M., \& Vajoczki, S. (2008). Developing and enhancing international collaborative learning. Journal of Geography in Higher Education, 32(1), 121-133.

International Geographical Union. (1935). The Fourteenth international geographical Congress, Warsaw, 1934. Geographical Review, 25(1), 142-148. 
Klein, P., \& Solem, M. (2008). Evaluating the impact of international collaboration on geography learning. Journal of Geography in Higher Education, 32(2), 245-267.

Lidstone, J., \& Stoltman, J. (2002). International understanding and geographical education. International Research in Geographical and Environmental Education, 11(4), 309-312.

Orford, E. (1938). Teaching for the good understanding between the peoples. In International Geographical Union (Ed.), Comptes rendus du congres International de Geographie. Amsterdam 1938 (pp. 16-22).Leiden: E.J. Brill.

Power, C. (2015). The power of education: Education for all, development, globalisation and UNESCO. Dordrecht: Springer.

Schneider, J. (1972). Les Commissions. In Geography through a century of international commissions. Paris: International Geographical Union.

Smith, H. (1944). The world federation of education associations. The Annals of the American Academy of Political and Social Science, 235(1), 107-112.,

Stoltman, J. (1997). The International Charter on Geographical Education: Setting the curriculum standard. Journal of Geography, 96(1), 32-32.

Stoltman, J. (2006). Turning points in geographic education. In J. Lidstone \& M. Williams (Eds.), Geographical education in a changing world: Past experience, current trends and future challenges (pp. 23-37).Dordrecht: Springer.

Stoltman, J., Lidstone, J., \& Kidman, G. (2017). The 2016 International Charter on Geographical Education. International Research in Geographical and Environmental Education, 26(1), 1-2.

Thomas, A. (1932). International understanding through the teaching of geography. Education, $53,250-254$.

UNESCO. (1949a). The teaching of geography and international understanding. Paris: Author.

UNESCO. (1949b). A handbook for the improvement of textbooks and teaching materials as aids to international understanding. Paris: Author.

UNESCO. (1949c). Some suggestions on the teaching of geography. Paris: Author.

UNESCO. (1951). A handbook of suggestions on the teaching of geography: Towards world understanding. Paris: Author.

UNESCO. (1965). UNESCO source book for geography teaching. London: Longman.

Ursula, R. (1955). Geography and international understanding. Journal of Geography, 54(4), $167-174$.

Wise, M.J. (1992). International geography: The IGU Commission on Education. In M. Naish (Ed.), Geography and education: National and international perspectives (pp. 233-246).London: University of London. 